\title{
Investigating the relationship between hemodynamic and metabolic parameters in portal triade occlusion following hemorrhagic shock ${ }^{1}$
}

\author{
Estudo da relação entre os parâmetros hemodinâmicos e metabólicos na oclusão da \\ tríade portal associada ao choque hemorrágico
}

\section{Mauro José Fontelles², Mario Mantovani ${ }^{3}$, Elcio Shiyoiti Hirano ${ }^{4}$, Rosana Celestina Morandin ${ }^{5}$}

\author{
1. Article from Trauma Surgery Division of the Department of Surgery, Faculty of Medical Sciences, Unicamp, Campinas - Brazil. \\ 2. Ph.D., Trauma Surgery. Professor of Human Anatomy, Universidade da Amazônia - Unama. \\ 3. Ph.D., Titular Professor, Chief - Trauma Surgery, Department of Surgery, Faculty of Medical Sciences, Unicamp. \\ 4. MSc., Trauma Surgery, Unicamp. \\ 5. Ph.D., Biology, Unicamp.
}

\begin{abstract}
Purpose: To determine whether metabolic and hemodynamic parameters are "mathematically" coupled in rats submitted to portal triad occlusion following controlled hemorrhagic shock state. Methods: Pearson's coefficient ( $r$-value) analysis was performed. Differences considered significant at $\mathrm{p}<0.05$ and $-0.50>\mathrm{r}>0.50$. Results: It was observed that there is a direct proportional relationship to $\mathrm{HCO}_{3}{ }^{-}$with $\mathrm{pCO}_{2}(\mathrm{r}=0.66)$, base deficit $(\mathrm{r}=0.87)$ and inverse with serum lactate $(\mathrm{r}=-0.54) . \mathrm{pCO}_{2}$ was directly associated with MAP $(\mathrm{r}=0.51)$, and inversely with $\mathrm{pH}(\mathrm{r}=-0.64)$. Hematocrit was directly associated with $\mathrm{HR}(\mathrm{r}=0.72)$ and $\mathrm{CI}(\mathrm{r}=0.76)$, and serum lactated was inversely associated with base deficit ( $\mathrm{r}=-0.61)$. Conclusion: In rats submitted to Pringle's maneuver during 15 minutes following hemorrhagic shock state, there is a mathematical coupling with a very good correlation between several hemodynamic and metabolic variables.
\end{abstract}

Key words: Pringle’s maneuve. Hepatic ischemia. Hemorrhagic shock.. Liver.

\section{RESUMO}

Objetivo: com a utilização de um modelo experimental, determinar se as alterações hemodinâmicas e metabólicas estão "matematicamente” relacionadas em ratos submetidos a estado de choque hemorrágico controlado seguido de isquemia hepática total. Métodos: O coeficiente de correlação de Pearson (valor r) foi utilizado para determinação das fórmulas matemáticas. Diferenças foram consideradas significativas com $\mathrm{p}<0,05$ e -0,50 $>\mathrm{r}>0.50$. Resultados: Encontrou-se uma relação diretamente proporcional para o $\mathrm{HCO}_{3}^{-}$ quando comparado com $\mathrm{pCO}_{2}(\mathrm{r}=0,66)$ e com o déficit de base $(\mathrm{r}=0,87)$; e inversamente proporcional quando comparado com o lactato sérico $(\mathrm{r}=-0,54) . \mathrm{O} \mathrm{pCO}_{2}$ esteve diretamente relacionado com a PAM $(\mathrm{r}=0,51)$ e inversamente com o $\mathrm{pH}(\mathrm{r}=-0,64)$. O hematócrito esteve diretamente associado com a freqüência cardíaca ( $\mathrm{r}=0,72)$ e, também, com o índice cardíaco $(\mathrm{r}=0,70)$. O lactato sérico esteve inversamente associado com o déficit de base $(r=-0,61)$. Conclusão: Em ratos submetidos ao estado de choque hemorrágico controlado, por 20 minutos, seguido de manobra de Pringle, por 15 minutos, diversas variáveis hemodinâmicas e metabólicas estão matematicamente associadas.

Descritores: Manobra de Pringle. Isquemia hepática. Choque hemorrágico. Fígado. 


\section{Introduction}

Trauma is the leading cause of death in patients under 40 years of age. Death from abdominal trauma is most commonly due to liver injury ${ }^{1,2}$. In these patients, the temporary portal triad occlusion (PTO), which is known as Pringle's maneuver, is the standard method for reducing the risk of massive hemorrhage during liver surgery, but there is still controversy over tolerance of the liver for ischemia ${ }^{3,4,5,6}$.

After a severe hepatic trauma, this maneuver produces dramatic alterations in the systemic hemodynamics during and immediately following portal triad occlusion. The exact etiology of these alterations remains unclear, but they have been linked to ischemia of the liver, as well as alteration of the splanchnic venous drainage resulting in intestinal ischemia ${ }^{7,8}$.

Thus, the purpose of this study was to evaluate the relationship between several metabolic and hemodynamic parameters in rats submitted to controlled hemorrhagic shock state associated to portal triad occlusion.

\section{Methods}

All the procedures undertaken in this work comply with the protocols approved in the Ethic Commission on Animal Experiment of the Biologic Institute of the Campinas University, Brazil.

Experiments were conducted in eight males Wistar rats (UNICAMP, Campinas, SP) weight ranging from 205-240g and eight weeks of age. The rats were under intraperitoneal anesthesia (IP) with a solution of cetamine cloridrate $(80 \mathrm{mg} / \mathrm{kg}$ - Cristália, São Paulo) plus xilazine cloridrate $(10 \mathrm{mg} / \mathrm{kg}$ - Bayer, São Paulo) and atropine $(0,05 \mathrm{mg} / \mathrm{kg}$ - Halex Star, São Paulo). After the anesthesia was induced they were placed in a supine position on a board with heat controlled electrically. The right femoral artery was exposed and a polyethylene catheter (PE 40), previously heparinezed, placed on it for control of the mean arterial blood pressure (MAP). Controlled hemorrhagic shock was attained through bleeding until the MAP reached $40 \mathrm{mmHg}$, for 20 minutes, then, volemic replacement with lactated Ringer's solution and blood (3:1) until the MAP reach $80 \mathrm{mmHg}$ was performed. A laparotomy paying due care to avoid excessive bleeding was made. The hepatoduodenal ligament was identified and clamped (Pringle's maneuver) with soft arterial clamps for 15 minutes. After clamp release a reperfusion period of 60 minutes was performed. Figure 1 shows each phase of the experiment as a function of time.

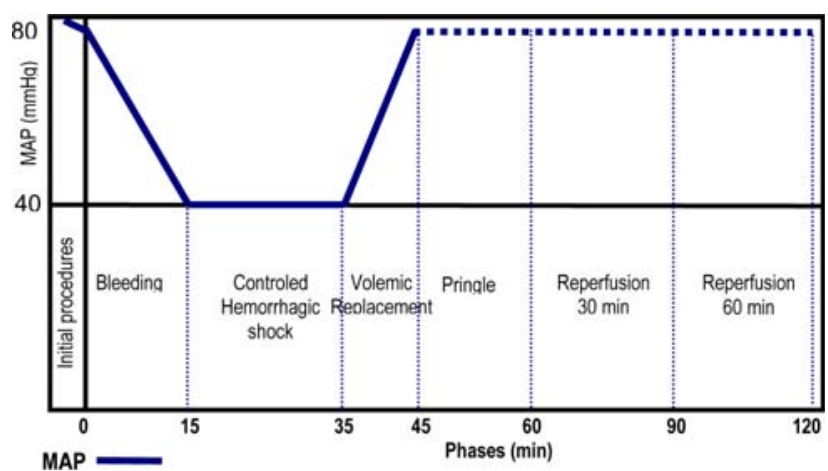

FIGURE 1 - Evolution of the experimental phases as a function of time.

The following parameters were monitored continuously: electrocardiogram (ECG), MAP, heart rate (HR), respiratory rate (RR), and rectal temperature (kept between $36^{\circ} \mathrm{C}-38^{\circ} \mathrm{C}$ by external heating). Blood gases $\left(\mathrm{pO}_{2}, \mathrm{pCO}_{2}\right)$, electrolytes $\left(\mathrm{Na}^{+}\right.$, $\mathrm{K}^{+}$), anion $\mathrm{HCO}_{3}^{-}$, Base Deficit (BD), serum lactate, hematocrit (Ht), and $\mathrm{pH} /$ blood were performed via arterial samples at baseline, after Pringles maneuver, and after 30-60 minutes of hepatic reperfusion.

The cardiac index (CI) was calculated using cardiac output (CO) and body surface area (BSA), as suggested by Carbonell et al. ${ }^{9}$ :

$\mathrm{CI}=\mathrm{CO} / \mathrm{BSA} \quad\left(\mathrm{ml} / \mathrm{min} / \mathrm{cm}^{2}\right)$, Where: $\mathrm{CO}=$ Systolic Volume $/$ Time $(\mathrm{ml} / \mathrm{min})$ and $\mathrm{BSA}=12.54$ $\mathrm{x}$ Body Weight $(\mathrm{BW})^{0.6}$.

Statistical analysis was carried out during the following periods: beginning of the reperfusion period, and 30-60 minutes after. On the comparison analysis between the hemodynamic and metabolic parameters the Pearson's coefficient ( $r$-value) was used. Differences considered significant at $\mathrm{p}<0.05$, and $0.50>r>0.50$.

\section{Results}

The results show a very good correlation between several hemodynamic and metabolic parameters during the experiment. Figures 2 to 3 show hemodynamic and metabolic variable as a function of time. 
The major finding of the current study was the proportional relationship between different variables in regarding $\mathrm{HCO}_{3}^{-}$, since $\mathrm{pCO}_{2}$ and base deficit are in direct relation, and serum lactate is in inverse relation to $\mathrm{HCO}_{3}^{-}$(Figure 3). A good correlation was also obtained when $\mathrm{pCO}_{2}$ was compared with MAP and

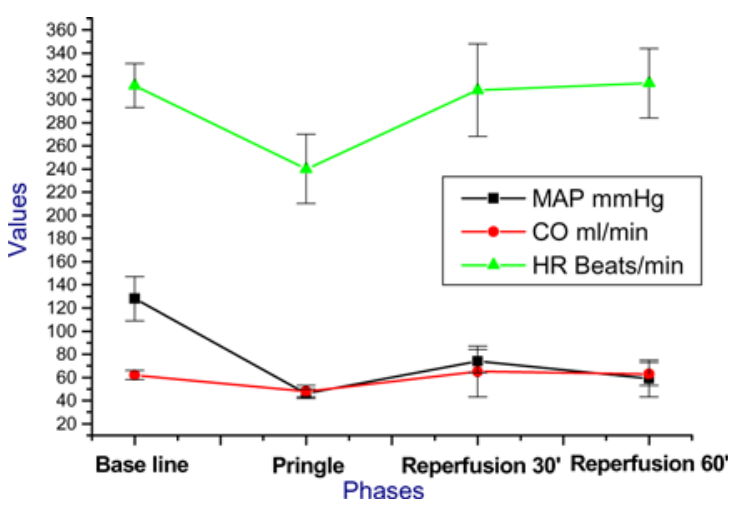

FIGURE 2 - Evolution of the hemodynamic parameters.
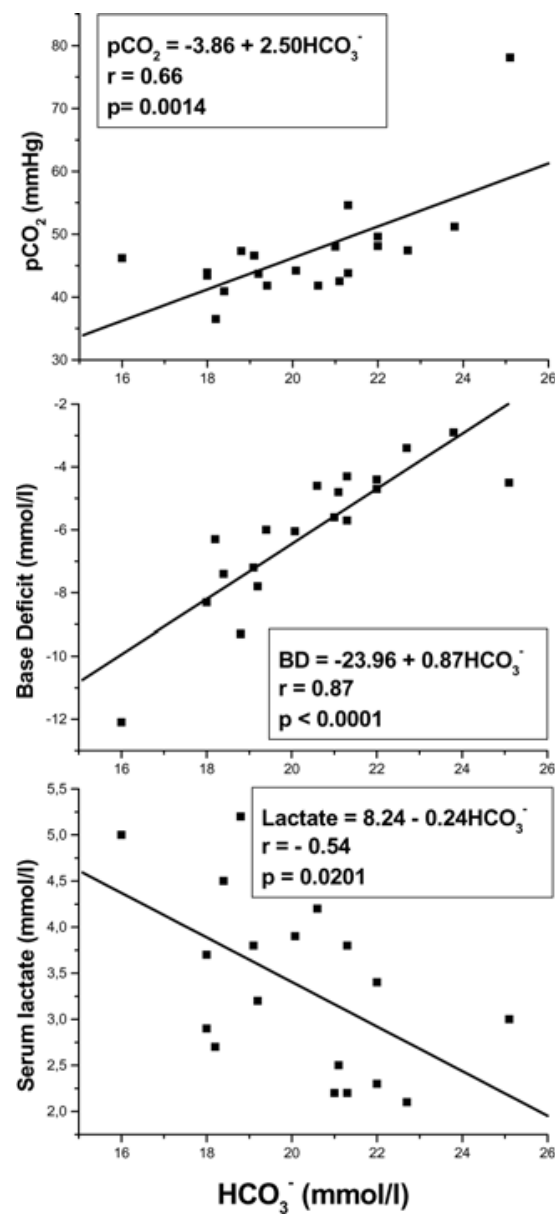

FIGURE 4 - Evolution of different parameters $\left(\mathrm{pCO}_{2}, \mathrm{BD}\right.$, Lactate) with Bicarbonate, showing corresponding equations, correlation coefficients and significance level
$\mathrm{pH}$ arterial blood (Figure 4). Figure 5 shows comparable data for hematocrit when associated with heart rate and cardiac index, and Figure 6 illustrate the inverse correlation between base deficit and serum lactate.

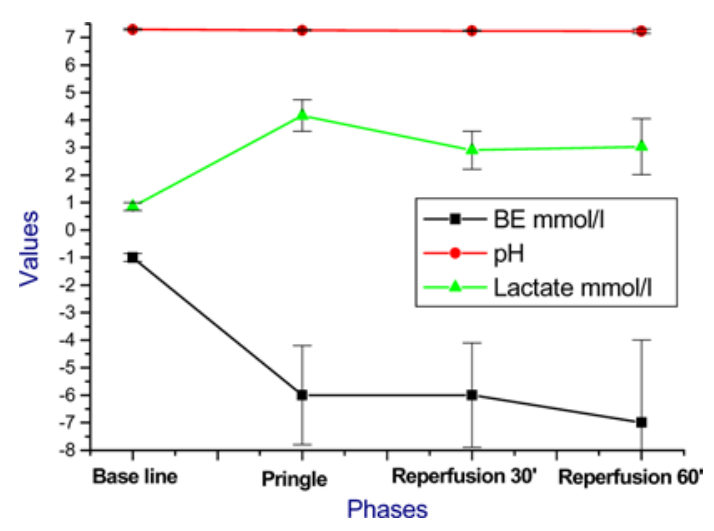

FIGURE 3 - Evolution of the metabolic parameters.

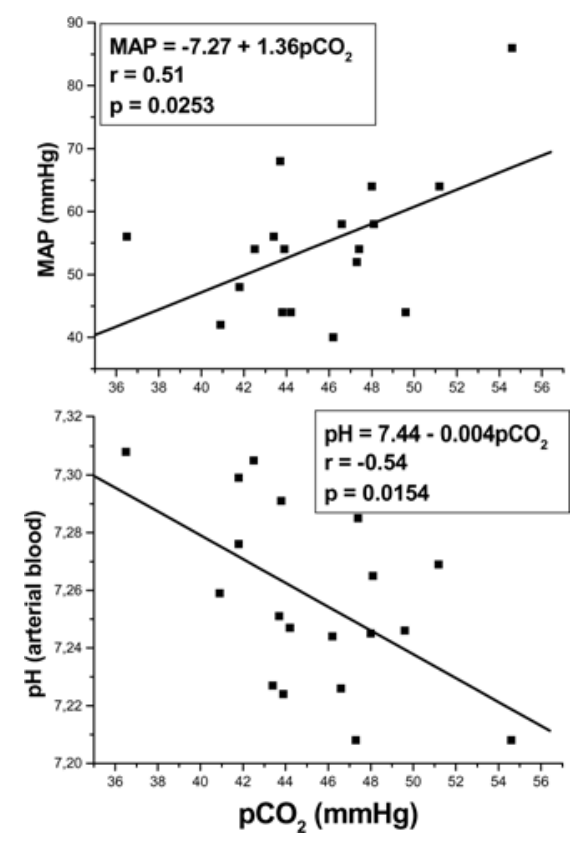

FIGURE 5 - Evolution of different parameters (MAP, pH/ Blood) with $\mathrm{pCO}_{2}$, showing corresponding equations, correlation coefficients and significance level 

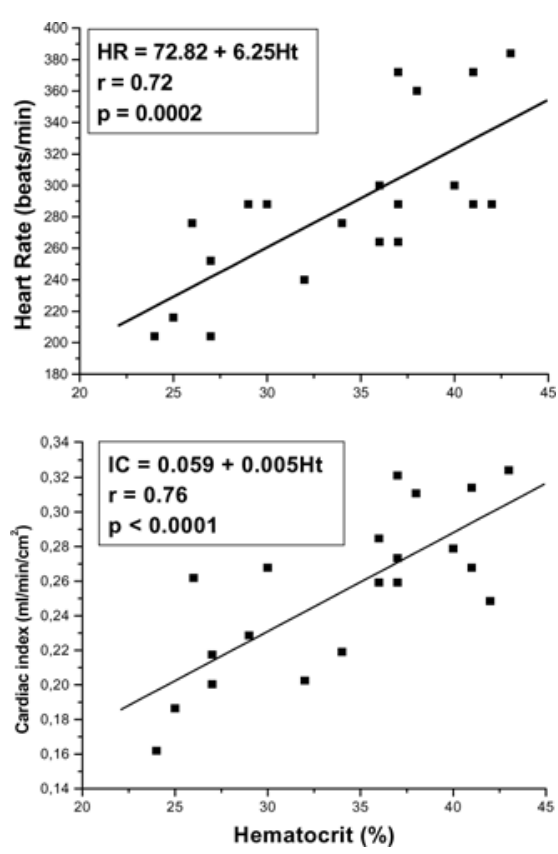

FIGURE 6 - Evolution of different parameters (HR, CI) with Hematocrit, showing corresponding equations, correlation coefficients and significance level

\section{Discussion}

A Complex hepatic injury is associated to high mortality rate, ranging from $40-80 \%$ and death can occur due severe hemorrhage ${ }^{10}$. In liver surgery following hepatic trauma, intraoperative bleeding is an important prognostic indicator of both morbidity and mortality, representing an independent risk factor of postoperative, and temporary clamping of hepatic pedicle is the standard method used to control hemorrhage $\mathrm{e}^{11,12}$.

Often referred to as the Pringle's maneuver, the PTO reduces the amount of hemorrhage from the liver parenchyma while the liver injury is surgically repaired. Frequently, this maneuver produces a profound effect on systemic hemodynamics, since the portal vein represents the principal venous drainage of the splanchnic bed, and its occlusion leaves only inadequate collateral pathways for the high volume of blood delivered to the splanchnic drainage ${ }^{7,13}$. As blood is reprised in the splanchnic bed, less blood returns to the heart to be returned to the systemic circulation, resulting in systemic shock state. On the other hand, the mechanism of ischemic injury of the liver following PTO has not yet been completely elucidated ${ }^{13,14}$.

In the same manner, disturbance in tissue

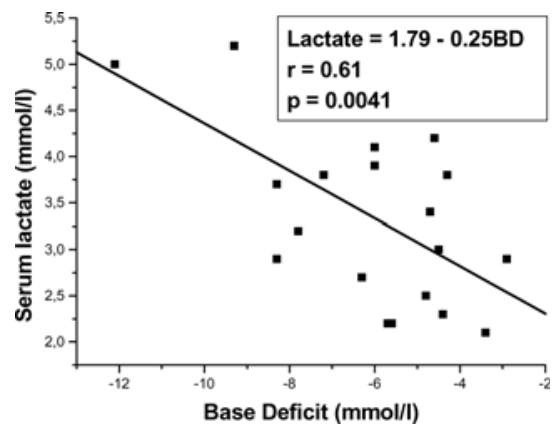

FIGURE 7 - Correlation of serum lactate values and BD, showing corresponding equation, correlation coefficient and significance level

perfusion and oxygenation are known to occurs during hemorrhagic shock, and is necessary a good understanding of its pathophysiological characteristics for adequate treatment, especially when associated with another aggravating condition, such as liver ischemia $^{15}$. Resuscitation from shock based on invasive hemodynamic monitoring has been widely used in hepatic trauma, since the early circulatory response has been shown to be predictive of survival in these patients ${ }^{16,17}$. Conventionally, tissue perfusion has been evaluated from indirect parameters, such as skin color and temperature, capillary refilling, urinary output, altered mental status, or by measurement of blood pressure, heart rate, and other signs and symptoms indicative of circulatory shock ${ }^{18}$. More specifically, tissue oxygenation has been inferred by metabolic parameter due to serum lactate, base deficit, pH arterial, and other blood measurements. However, in literature, the relationship between these variables has not been evaluated, and we hypothesize that these parameters are mathematically coupled in rats submitted to PTO following controlled hemorrhagic shock state.

In our experimental model, PTO produces severe alterations in systemic hemodynamics after few minutes of occlusion with a decrease in the systemic circulating blood volume. As a result, there was 
decreased venous return and an accentuated drop in $\mathrm{CO}$ and MAP, triggering a reflexively vasoconstriction. Despite intensive vasoconstriction, MAP was not maintained and systemic hypotension and bradycardia occurred likely as a parasympathetic reflex $^{19}$. As referred by Gonce et al. ${ }^{7}$, as CO and MAP decrease in presence of severe vasoconstriction, systemic tissue perfusion is impaired, and the low CO combined with portal hypertension produce profound splanchnic ischemia. After release of the clamp a partial hemodynamics recovery was detected with an improvement in CO, MAP and metabolic parameters, however with a persistent metabolic acidosis during the reperfusion period. The direct relationships between $\mathrm{pCO}_{2}$ and $\mathrm{BD}$ with $\mathrm{HCO}_{3}$, found in the experiment described here, could be related to a compensatory mechanism to maintain the corporal homeostasis since $\mathrm{pH}$ value remains almost unaltered. In the same manner, a direct relationship between hemodynamic and metabolic variables also was observed, especially when hematocrit or $\mathrm{pCO}_{2}$ values were related to MAP, CI and HR.

In summary, the most relevant findings from this study is that, in rats submitted to Pringle's maneuver following hemorrhagic shock, there is a mathematical coupling with a very good correlation between several hemodynamic and metabolic variables.

\section{References}

1. Patcher HL, Liang HG, Hofstetter SR. Liver and biliary tract trauma. In: Mattox KL, Feliciano DV, Moore EE. Trauma. 4th ed. New York: McGraw-Hill, 1999. p. 633-82.

2. Cirocchi R, Contine A, Mazieri M, Bisacci R, Fabbri C, Bisacci C, Fabbri B. Il packing periepatico associato a wrapping nel trattamento dei grandi traumi epatici bilobari. Chir Ital. 1999;51(3):259-64.

3. Smith AC. Pringle’s maneuver. Curr Surg. 1982;39(1):12-7.

4. Uchinami M, Muraoka R, Horiuchi T, Tabo T, Kimura N, Naito Y, Yoshikawa T. Effect of intermittent hepatic pedicle clamping on free radical generation in the rat liver. Surgery. 1998;124(1):49-56.

5. Man K, Fan ST, Ng IO, Lo CM, Liu CL, Yu WC, Wong J. Tolerance of the liver to intermittent Pringle maneuver in hepatectomy for liver tumors. Arch Surg. 1999;134(5):533-9.

6. Sakamoto Y, Makuuchi M, Takayama T, Minagawa M, Kita, Y. Pringle's maneuver lasting 322 min. Hepatogastroenterology. 1999;46(25):457-8.
7. Gonce ME, Brackett DJ, Squires RA, Gibson DD, Balla AK, Lerner MR, McCay PB, Pennington LR. Development of circulatory and metabolic shocks following transient portal triad occlusion. J Surg Res. 1995;59(5):534-43.

8. Towfigh S, Heisler T, Rigberg DA, Hines OJ, Chu J, McFadde DW, Chandler C. Intestinal ischemia and the gut-liver axis: an in vitro model. J Surg Res. 2000;88(2):160-4.

9. Carbonell LF, Salom MG, Salazar FJ, Garcia-Estañ J, Ubeda M, Quesada T. Normal hemodynamic parameters in conscious Wistar rats. Rev Esp Fisiol. 1985;41(4): 437-42.

10. Asensio JA, Demetriades D, Chahwan S, Gomez H, Hanpeter D, Velmahos G, Murray S, Shoemaker W, Berne TV. Approach to the management of complex hepatic injuries. J Trauma. 2000;48(1)66-9.

11. Isozaki H, Aadam R, Gigou M, Szekely AM, Shen M, Bismuth H. Experimental study of the protective effect of intermittent hepatic pedicle clamping in the rat. Br J Surg. 1992;79(4):310-3.

12. Man K, Fan ST, Ng IO, Lo CM, Liu CL, Wong J. Prospective evaluation of Pringle maneuver in hepatectomy for liver tumors by a randomized study. Ann Surg. 1997;226(6):704-13.

13. Kazuo H, Nishida T, Seiyama A, Ueshima S, Hamada E, Ito T, Matsuda H. Recovery of blood flow and oxygen transport after temporary ischemia of rat liver. Am J Physiol. 1998;275 (1 Pt 2): H243-9.

14. Ling YQ, Shibamoto T, Honda T, Kamikado C, Hironaka E, Hongo M, Koyama S. Increased sinusoidal pressure is associated with early liver weight gain in ischemiareperfusion injury in isolated perfused rat liver. J Surg Res. 2000;88(2):70-7.

15. Kakihana Y, Yoshimura N. New monitoring strategies during shock. Nippon Geka Gakkai Zasshi. 1999;100(10):648-51.

16. Holm C, Melcer B, Hürbrand F, Würl HH, Von Donnersmarck GH, Mühlbauer W. haemodynamic and oxygen transport responses in survivors and nonsurvivors following thermal injury. Burns. 2000;26(1):25-33.

17. Shoemaker WC, Wo CC, Yu S, Farjam F, Thangathurai D. Invasive and noninvasive haemodynamic monitoring of acutely ill sepsis and septic shock patients in the emergency department. Eur J Emerg Med. 2000;7(3):169-75. 18. Tatevossian RG, Shoemaker WC, Wo CC, Dang AB, Velmahos GC, Demetriades D. Nonivasive hemodynamic monitoring for early warning of adult respiratory distress syndrome in trauma patients. J Crit Care. 2000;15(4):151-9.

19. Akagi M, Akagi R. hepatic ischemia-reperfusion injury to the cardiovascular system in rats. Japanese $\mathrm{J}$ Pharmacol. 1992;58(2):306-11.

\section{Acknowledgments}

The authors would like to thank Mr. Edilson Silva Jr. for his helpful and review of the manuscript. 
Correspondence:

Dr. Mauro José Fontelles

Rua Antônio Barreto, 983/1502

66055-050 Belém - Pará

Phone: (91)225-1850

mikefox@uol.com.br
Conflict of interest: none Financial source: none

Received: September 10, 2004

Review: November 25, 2004

Accepted: January 03, 2005

How to cite this article:

Fontelles MJ, Mantovani M, Hirano ES, Morandin RC. Investigating the relationship between hemodynamic and metabolic parameters in portal triade occlusion following hemorrhagic shock. Acta Cir Bras. [serial online] 2005 Jan-Feb;20(1). Available from URL: http://www.scielo.br/acb

*Color figures available from $\underline{w w w}$. scielo.br/acb 